\title{
Political Affiliation of Canadian UNIVERSITY PROFESSORS
}

\author{
M.R. NAKHAIE \\ BARRY D. ADAM
}

\begin{abstract}
The social role of universities has been the subject of a lengthy debate as to whether those who teach in the academy are system-legitimizing conservatives or radicals helping to generate critical thinking that challenges the status quo. The aim of this paper is to evaluate political affiliations of Canadian university professors based on a national survey conducted in 2000 . The study shows that Canadian professors' political affiliation can be identified as either left or right depending on how the political orientation of political parties is conceptualized. University professors tend to vote more for the Liberal Party than other parties, and view it as centrist party. Moreover, the study highlights a complex and non-monolithic picture of the Canadian academy. University professors are not politically homogenous and party vote depends on the prestige of their university, their discipline, gender, ethnicity, marital status, generation, and agreement with liberalism.
\end{abstract}

Résumé. Le rôle social des universités fait depuis longtemps l'objet d'un débat sur l'orientation politique des professeurs : sont-ils des conservateurs qui légitiment le statu quo, ou des radicaux qui aident à créer une pensée critique qui le conteste? Le but du présent article est d'évaluer les affiliations politiques des professeurs canadiens telles qu'elles se dégagent d'un sondage national effectué en 2000. L'étude montre que leur affiliation politique peut être décrite comme de gauche ou de droite, selon la conception qu'on a de l'orientation des partis politiques. Ils votent plus souvent pour les Libéraux que pour d'autres partis, les voyant comme un parti du centre. D'ailleurs, l'étude donne des universités canadiennes un tableau complexe et nullement monolithique. Les professeurs n'ont pas de vues homogènes, ils votent en partie selon le prestige de leur université, leur discipline, leur sexe, leurs antécédents ethniques, leur situation de famille, leur âge et leur attitude envers le libéralisme.

* This project is supported by a grant from the Social Science and Humanities Research Council of Canada. We also thank the anonymous reviewers for their helpful comments. 
$\int$ he social role of the modern academy has been the subject of a lengthy debate between those who extol its capacity to generate critical thinking and preserve a free zone of systematic and rational investigation, and critics who point out its role in producing well-socialized professionals acting on behalf of the state and corporate sectors. On the one hand, academic institutions are seen as a major source of system legitimization, socializing a large sector of the population into system-reproducing modes of thought. On the other hand, these institutions are seen as a major source for the inculcation of critical outlooks and challenges to the status quo (see, for example, Lipset and Dobson 1972; Boggs 1993; Jacoby 1987). This typology coincides with the common practice of dividing intellectuals into ideological and utopian (Mannheim 1955), traditional and organic (Gramsci 1971), intellectuals and intelligentsia (Gouldner 1979), responsible and combative (Chomsky 1978), numbersmiths and wordsmiths (Nozick 1998), and useful and genuine (Smith 2001).

The most common questions arising out of the study of intellectuals are whether or not they are politically oriented and, if so, under what conditions intellectuals become an intelligentsia critical of social order. In Canada, it is customary to designate the Royal Society as the country's intellectual elite, members of which are drawn from among university professors (Ogmundson and McLaughlin 1994:2-4). Thus, Porter (1965:493, 505), writing for a period in the intellectual history of English Canada which was not remarkable for social criticism, argued that the Canadian intelligentsia was heavily weighted in favour of conservative traditionalists who lacked social criticism and participation in the political arena. Speaking of the Royal Society of Canada, Section II, composed almost exclusively of the British charter group, Porter stated that very little of what they wrote could be considered social criticism. "With few exceptions, their attitudes and values are conventional" (1965:500). He attributed their conservatism to the attitude expressed by Harold Adams Innis that politics are "nasty things for scholars to play around with" (1965:503). Similarly, Section III of the Royal Society of Canada is made up of the "men of science, the leaders in the empirical, non-ideological disciplines ... not linked to political power" (1965:513). However, Section I, containing French literature, civilization, and social sciences had quite a different composition in Porter's time; they were more active in the public sphere (1965:503).

Similar distinctions are developed by other scholars. Brym and Myles (1989:447-448) concluded that the Canadian political system severely constrains intellectuals' open advocacy of partisan policy. In 
the Anglo-Canadian system, intellectuals are rewarded for disengagement and penalized for engagement. Regarding francophone intellectuals, Pinard and Hamilton (1989:296) spoke of their "unique" character whose parties of choice - the Parti Québécois and the New Democratic Party - have been distinctively antiestablishment. Brooks and Gagnon (1987:39) stated that engagement was more characteristic of social scientists in French Canada, involving direct participation in the mobilization of interests through parties, social movements, unions, and organs of contemporary criticism.

This short review is indicative of a paucity of empirical research on the political orientation of Canadian intellectuals, in general, and that of university professors, in particular. The only survey-based sociological study of university professors, conducted in 1987 (Nakhaie and Brym 1999), showed that Canadian professors from lower class backgrounds; those in lower ranks; with lower publication counts; in social sciences, education, and humanities; from the less prestigious universities; Francophones; and women were more likely to have a left-leaning political orientation than their counterparts.

Although Canadian literature on the political behaviour and attitudes of university professors is limited, this topic is a flourishing industry in the United States. Lipset and his colleagues in a series of articles and books (1970; 1972; Ladd and Lipset 1971; 1973a; 1973b; 1975) evaluated the political ideology and behaviour of US faculty. They found that, compared to the general population, the political orientation of academics is more left-leaning. The electoral preference of the social scientists in the 1968 and 1972 elections was more in favour of Democratic candidates and less for Republican candidates, a pattern which was reversed in the natural sciences and business. For seven succeeding elections, from 1944 to 1972 , professors were decidedly more likely to vote for Democratic candidates than were those in professional/managerial and clerical/sales occupations. Although professors' vote for Democratic candidates was slightly less than manual workers' vote in 1944 and 1948 elections, this pattern changed dramatically after the 1948 election. Thus, from 1952 to 1972, professors were more likely to vote for a Democratic candidate than manual workers by $4-12 \%$. In other words, in class vote terminology, professors voted in a more left-liberal direction than did working class voters. These findings also echo those of Halsey and Trow (1971) for British academics: university teachers' political affiliations are more like the working class than the upper middle class.

Ladd and Lipset's studies also questioned the class theory of political ideology and behaviour in other areas. They showed that professors in 
elite universities were more supportive of Democratic candidates. They were more likely to consider themselves liberal than conservative when compared to those in nonelite universities. Social science professors with numerous publications and with a higher index of academic status were also more likely to support a Democratic candidate and to consider themselves as libertarian. In general, professors with higher academic achievement and those in more prestigious universities and/or in "liberal arts" disciplines scored higher on liberalism and voting for a Democratic candidate. Ladd and Lipset attributed their finding to a culture of criticism among the most achieving academics. "If the natural posture of the intellectual is that of critic,... then the most intellectually achieving among academics might be expected to display relatively more leftof-center commitments" (Ladd and Lipset 1973a:21). Ladd and Lipset $(1975: 87,148)$ concluded that applying the "class theory of politics to academe is often ill advised" and that "the academy turns the class theory of politics on its head." The Canadian results on the political ideology of professors are, however, inconsistent with Ladd and Lipset's findings for social class, publication, and rank. This difference may be due to the fact that Ladd and Lipset's research did not control for relevant variables and relied mainly on bivariate analyses.

A recent surge in interest in the political orientation and affiliation of university professors has emerged in the United States, partly due to a general ascent of conservatism in the 1990s. Conservatives argue that radicals and activists of the 1960s joined universities, shifting university opinion sharply to the left (Kimball 1990). The thrust of the national political debate in the US tends toward the question of whether universities are dominated by left-wing individuals overwhelmingly sympathetic to the Democratic Party and whether such sympathies limit recruitment of faculty who are more conservative (Thomson 1990), casting doubt on the intellectual diversity of universities (Kimball 1990, Horowitz and Lehrer 2002).

Against this backdrop, Rothman et al.'s (2005) study of 1,643 faculty members from 183 academic institutions surveyed by Angus Reid showed that liberals and Democrats substantially outnumber conservatives and Republicans by a ratio of 5:1. Klein and Stern (2005) studied memberships in anthropology, sociology, political science, economics, history, and philosophical associations in 2003 and showed that $79.6 \%$ of respondents reported voting Democrat and only $9.3 \%$ reported voting Republican. Cardiff and Klein (2005) evaluated party registration of tenure-track faculty at 11 California universities and showed a 5:1 ratio of Democrats to Republicans. Overall, $45 \%$ of the tenure-track faculty was 
registered as Democrat and 9\% as Republican. The party affiliation of others was "unknown" (19\%), "declined to state" (13\%), indeterminate (10\%), Green (1\%), and others (1\%). Gross and Simmons (2007) studied 1,471 professors teaching in universities where undergraduate degrees are awarded and showed that $51 \%$ of professors placed themselves as Democrats and $13.7 \%$ as Republicans, with $35.3 \%$ as Independent. Generally, the American studies suggest that university professors are over four to five times more likely to vote for the Democratic than Republican party. This is significantly higher than the extent of party sympathies in Sweden where among social scientists in business administration, economic history, economics, gender studies, law, political science, and sociology, for every 1.3 academics on the right there is one in the left (Berggren et al. 2007). ${ }^{1}$

This new research, consistent with the older generation of research, also showed that liberalism and support for the Democratic Party tend to be higher in liberal arts disciplines (social sciences, humanities, arts, and education) while natural sciences (sciences, engineering, and business) tend to be more conservative and Republican. Moreover, the research points to significant within-discipline differences. For example, Cardiff and Stern (2005) show that the ratio of Democrats to Republicans in biology was 10.7:1, while Rothman and Lichter (2007) showed this ratio to be $4: 1$. These figures are higher than that of natural sciences in general. In comparison, the ratio for political science stood at 6.5:1 (Cardiff and Stern 2005) and 7:1 (Rothman and Lichter 2007).

Although the study of the political affiliation of professors in the US is flourishing, our knowledge of their Canadian counterparts is lacking. There are several issues which require attention with respect to Canada. The party system in the US is bifurcated into Democratic and Republican parties. In the US context, a vote for the former is viewed as left-leaning and liberal, while a vote for the latter is viewed as right-leaning and conservative. Since most professors in the US vote for the Democratic Party, universities can be seen by conservatives as the bastion of leftist and radical professors.

The Canadian multiparty system challenges this simple dichotomy. The New Democratic Party is the only party which can seriously be viewed as a "social-democratic left" (Alford 1963) or a "left-wing" party (Brym and Myles 1989). The Conservative Party can appropriately be viewed as a "conservative-right" (Alford 1963) or a right-wing party.

1. Left parties included the Social Democratic Party, the Left Party, and the Green Party while right parties included the Christian Democrats, the Moderate Party, the Centre Party, and the Liberal Party. 
Similarly, the Reform Party, founded in 1987, was a "rightist populist" party (Tremblay 1998). However, it is questionable whether the Liberal party can be classified as a "centre-left" (but see Alford 1963) or a leftist party. Grant (1965) pointed to the fact that, at times, the Liberal party acts as a conservative party. Ogmundson (1975a) argued that the Liberal party is actually a conservative party, at least in its economic platform. This conceptualization was corroborated by Zipp (1978) and Zipp and Smith (1982) who viewed both the Liberal and Conservative parties as conservative-right parties. Similarly, although the Bloc Québécois may be viewed as being on the "centre-left of the ideological scale" (Tremblay 1998), on some issues it has a conservative platform, or at least it has no particular unifying ideology other than that of "defence of the interests of all Quebecers in Ottawa." The BQ was founded in 1993 by Lucien Bouchard, an ex-cabinet minister under Conservative Prime Minister Brian Mulroney, and has supported policies related to severe cuts to social spending such as the "zero deficit" campaign. In sum, the Canadian multiparty system complicates easy generalization along a left-right ideological spectrum.

Another difference between the US and Canada is the extent to which universities have been under attack because of the political affiliation of professors. Notonly is the US known for its "exceptionalism" (Lipset 1996), but also for a history of anti-intellectualism (e.g., McCarthyism) (Hofstadter 1963), that is less evident in Canada. The Canadian political landscape includes a number of intellectuals with long academic careers. Both Pierre Trudeau and Stéphane Dion came to leadership positions in the Liberal Party following lengthy academic careers; NDP leaders Ed Broadbent and Jack Layton both hold PhDs and have had academic appointments, as did Lester Pearson. In the United States, there has been no parallel mobility of academics since the presidency of Woodrow Wilson (1913-1921). Furthermore, the US has several conservative "think tanks" and media outlets aligned with the Republican ascendancy in Congress and the White House over most of the last quarter century. These conservative forces have pursued a concerted agenda of policing "liberalism" on a number of fronts, including public broadcasting, funding for the arts, and university teaching (Scatamburlo 1998). Canadian equivalents to these organizations, such as the Fraser Institute and the National Post, are comparatively lower profile and show less interest in these areas.

These significant contextual differences between the US and Canada make generalizations about universities' political orientation problematic. This study presents systematic survey-based evidence on profes- 
sors' party affiliation. The focus is on professors' voting behaviour and political self-identification, differentiating by sociodemographics and contextual characteristics.

\section{DATA}

The data source is the survey of the Academic Profession in Canada: Political and Ethnic Culture of Canadian Universities. The survey was administered to a stratified random sample of full-time faculty members in 2000 when the Liberal Party dominated the political landscape and before the election of the Conservative minority government. The mailed questionnaire included questions on sociodemographics, socioeconomic background, voting behaviour, political orientation, and attitudes towards ethnic inequalities. The questionnaire was sent to 10,000 professors. The sample selection procedure used systematic selection within 12 strata based on the province and size of the university. The sample was not selected with equal probabilities, and a weight was assigned to each case (see Nakhaie 2007). ${ }^{2}$

The response rate of $34 \%(\mathrm{~N}=3,318)$ raises the possibility of a response bias. Although the response rate appears to be low, it is within the range typically reported for self-administered questionnaires (see Neuman 2006:295-296). In fact, Klein and Stern's (2005) surveys of six US scholarly associations resulted in response rates of $22.6-36.2 \%$. Nonetheless, we tested for the representativeness of the survey. Table 1 shows that the distribution of the sample and the academic population by field, rank, and gender are virtually identical. Chi Square tests of significance revealed no difference between the academic sample and the academic population. Similarly, data submitted by the universities to the Federal Contractors Program show that members of visible minority groups make up $10.3 \%$ of the university faculties across the country (Kobayashi 2002), a figure close to the $9.7 \%$ for this sample. Therefore, the response bias should be negligible.

2. A basic weight was created which is equal to the inverse of the probability of selection for each sample record. Thus: $\mathrm{WT}=1 / \mathrm{f}=\mathrm{Nij} / \mathrm{nij}$. Where $\mathrm{Nij}=$ the total population of academics in region $\mathrm{i}$ and university size stratum $\mathrm{j}$; nij $=$ the sample population of academics in region $i$ and university size stratum $j$; and $f=$ the sampling fraction. Second, the statistical weights of the responding academics were adjusted by uniformly distributing among them the statistical weights of nonrespondents, based on the assumption that the two groups are similar in characteristics of interest. Thus: NRCF $=$ nij/rij. Where $\mathrm{NRCF}=$ the nonresponse correction factor; and rij $=$ the number of responding academics in region i and university size strata j. Finally, population weight was calculated by: POPWT $=$ WT $*$ NRCF and then a sample weight (SAMWT) was applied to the analyses: SAMWT $=$ POPWT/mean of the POPWT (see J. Lennards 1990). Separate analysis using unweighted data produced substantially similar results. 
Table 1. Frequency Distributions for Full-time Faculty in Canadian Universities

\section{Field}

Fine and Applied Arts

Humanities

Social Sciences

Engineering and Applied Sciences

Health Profession

Mathematics and Physical Sciences

Agriculture and Biological Sciences

Total

\section{Gender}

Male

Females

Total

Academic Rank

Full Professor

Associate Professor

Assistant Professor

Other

Total
Population (1998-99) Sample (2000)

$\begin{array}{rrrr}N & \% & N & \% \\ 2526 & 7.6 & 224 & 6.8 \\ 1364 & 4.1 & 121 & 3.6 \\ 5204 & 15.6 & 504 & 15.2 \\ 8858 & 26.5 & 900 & 27.1 \\ 2691 & 8.1 & 258 & 7.8 \\ 5987 & 17.9 & 583 & 17.6 \\ 4291 & 12.8 & 459 & 13.8 \\ 2505 & 7.5 & 269 & 8.1 \\ 33426 & 100 & 3318 & 100\end{array}$

$\begin{array}{rcrc}24646 & 72.9 & 2315 & 70.3 \\ 9155 & 27.1 & 980 & 29.7 \\ 33801 & 100 & 3295 & 100 \\ & & & \\ 13867 & 41.0 & 1440 & 44.5 \\ 11702 & 34.6 & 1106 & 34.2 \\ 6647 & 19.7 & 470 & 14.5 \\ 1585 & 4.7 & 211 & 6.8 \\ 33801 & 100 & 3227 & 100\end{array}$
University and Colleges of Canada (http://www.auc.ca).

\section{Measurement}

The ultimate dependent variable is political affiliation as measured by voting for a political party. The survey asked respondents if they voted in each of 1993 and 1997 elections and if so, for which party. Since the survey was conducted just months before the 2000 election, respondents were also asked, "if there was an election today, for which party would you vote?"

We are interested in knowing the effect of the "usual suspects" in voting behaviour of the general population. These include region, ethnicity, nativity, religiosity, age, gender, marital status, and income. Regions include: East, Quebec, West, BC, and Ontario (reference category). For ethnicity, the survey asked: "To which ethnic or cultural group(s) did your father's ancestors belong?" It also asked if they were members of visible minorities. We used replies to these questions and developed a 6 category measure of ethno-racial origins: British (reference categories), French, other Europeans, visible minorities, Jewish, and self-identified Canadian. Nativity was coded as Canadian born $=1$, immigrant $=0$. Gender was coded as male $=1$, female $=0$. Age was measured in years; income, by 
total personal income. To deal with its curvilinear relationship to age and rank, we used the natural log of income. Since income had 7.1\% missing cases, a dummy variable for missing income was included in the model in order to control for the effect of income mean plugging. Religiosity was measured by a question asking respondents if they consider themselves to be religious on a 4 point scale from: nonreligious (coded 1) to deeply religious (coded 4). Academic rank included: professors, associate professors, assistant professors (reference), and others. Reported marital status was used to generate dummies representing the married, single (reference category), divorced/separated/widowed, and cohabiting. Only married/cohabiting versus other categories was found useful.

University disciplines and professors' institutional prestige are also important for political culture and ideological orientations (see Ladd and Lipset 1975; Nakhaie and Brym 1999). Field of specialization was measured by a question that asked respondents about the department and faculty in which their main teaching appointment is held. This variable was coded into: education, arts, humanities, social sciences, business, and sciences (reference category). Institutional standing was measured by Gourman's (1998) ranking of Canadian universities. We also analyzed Maclean's ranking of universities. Although results regarding university prestige were essentially the same, we relied on Gourman's ranking. Maclean's national reputational ranking included only 25 universities and thus inclusion of Macleans' ranking would have increased missing cases by about $40 \%$. Professor's prestige is measured by publication productivity rate. The survey asked respondents to list numbers of published work and reports during their career. A new measure was constructed which applied the following weights for type of publication (see Nakhaie and Brym 1999; Nakhaie 2002): published report=2, edited book $=3$, refereed article $=3$, article in edited books $=2$, book $=14$. The publication weights were summed and divided by three (3). This weighted measure of research productivity equals the average number of refereed articles equivalent publications for the last five years. Given the fact that many professors publish little and some have a significantly high publication output, this measure is normalized using log transformation. Log of publication is used in the regression analyses.

Finally, we are interested in the extent to which professors' own level of political orientation and their socialization in an oppositional culture can help explain their political affiliation. Since universities became somewhat radicalized during the late 1960s and early 1970s due to the Vietnam War and related student movements, it may be expected that those who received their degree during the "radical era" would be more left-leaning than those who received their highest degree before or 
after this period. Therefore, dummy variables were created for those who received their highest degree before 1968 or after 1980 , with those who received their degree between 1968 and 1980 as the reference category.

\section{Analysis}

Table 2 shows political affiliation of professors and the general public for each of 1993, 1997, and 2000 elections. Over $40 \%$ of professors voted for the Liberal Party, just over $10 \%$ for Conservative parties (PC/Reform/Alliance), $7 \%$ for the Bloc Québécois, and about 30\% for the NDP. The Liberal vote among professors is comparable to that of the population (around $41.5-46.5 \%$ versus $38.5-41.3 \%$ ), the Conservative and the

Table 2. Party Vote: Canadian Professors and Population

Liberal

Professors' Affiliation

Reform (Alliance in 2000)

1993

Election Year

Progressive Conservative

2.4

1997

$2000 *$

Bloc Québécois

10.9

7.7

30.1

2.7

4.7

46.5

41.9

NDP

100.0

No Answer

2,721

$\mathrm{N}$

Did (Will) Not Vote

18.0

3.8

5.1

6.9

7.9

29.0

28.4

5.9

General Population's Affiliation

Liberal

41.3

18.7

16.0

2.1

5.4

Reform (Alliance in 2000)

Progressive Conservative

13.5

Bloc Québécois

6.9

4.0

100.0

NDP

3.6

100.0

2,608

Other

100.0

2,833

21.4

Total

$13,667,67$

14.6

40.8

38.5

25.5

19.4

12.2

10.7

10.7

8.5

11.0

2.2

$\mathrm{N}$

Did (Will) Not Vote

29.4

100.0

100.0

Professor to Population Ratio

Liberal

1.00

$12,985,874$

$12,857,185$

Reform (Alliance in 2000)

0.13

1.21

38.8

Progressive Conservative

0.68

0.20

1.03

Bloc Québécois

0.57

0.39

0.20

NDP

4.36

0.74

0.47

Other

0.75

2.58

0.64

Did (Will) Not Vote

0.61

1.31

3.41

2.68

* If election held today. 
Bloc vote is lower than that of the population (10.8-13.3\% and 6.9-7.9\% versus $34.7-37.7 \%$ and $10.7-13.5 \%$, respectively), while professors tend to vote more for the NDP than we would expect from the general population (28.4-30.1\% versus $6.9-11 \%)$. University professors vote NDP about three times more than the general population.

We can also determine political tendencies in the academy by professors' ratings of their own political orientation. The survey first states that "political attitudes have often been described as being on the 'left' or on the 'right.' Does a left-right continuum make sense to you in locating your political views?" Those who said "yes" (65.9\%) were prompted to locate their political orientation on a 7 point scale 1 being left, 4 being centre and 7 being right. Those who said "no" were asked to make a choice in this scale, too. Among the "no" respondents $45 \%$ chose 4 (centre) as their forced response. We combined both responses as the measure of professors' liberalism.

Table 3 presents results of professors' own rating of left/right political orientation. Combining those who scored 1 and 2 as left, 3,4 , and 5 as center, and 6 and 7 as right, we notice that $25.5 \%$ of professors view themselves as left-leaning, $62.3 \%$ as centre and $4.5 \%$ as right-leaning. Therefore, the ratio of left to right among professors is about 5:1. For the US, Gross and Simmons (2007; also see Jaschik 2007) showed that $44.2 \%$ of professors scored to the left of a 7 point liberalism scale, $9.2 \%$ to the right and $46.6 \%$ scored on the middle three categories. American professors are more left and Canadians more to the centre.

The choice of recoding a 7 point or 10 point left-right scheme may depend on researchers' own political interests. ${ }^{3}$ For example, Rothman and Lichter (2007) recoded a 10 point scale so that $1,2,3$, and 4 are considered left and 7, 8, 9, and 10 as right. They showed that $62 \%$ of the faculty scored to the left of centre and only $12 \%$ to the right with $26 \%$ as the middle of the road (see also Rothman et al. 2005; Klein and Stern 2007). Canada-US comparison suggests that professors are more to the left than right in both countries. Moreover, the size of the centre and the extent of left-right ratios depend on the survey question and the way scales are collapsed. Furthermore, the social context seems to have a significant effect on the size of these groupings. For example, Swedish social sci-

3. In order to validate the reclassification presented here, we constructed a scale made of 13 questions on various ideological dimensions of leftism (egalitarianism, support for unions, gender, and etho-racial equality) and calculated the mean leftism for each category of the 7 point left-right scale. We noticed that the difference in mean leftism between categories 3 and 4 in the left-right scale is less than that between 3 and 2 . Similarly, the difference between category 4 and 5 is less than that between 5 and 6 . This evidence suggests perhaps that combining categories 3 and 5 with 4 make more sense than combining 3 with 2 and 1 and 5 with 6 and 7 . 
Table 3: Political Orientation of Professors and the General Population

Does Left/Right distinction make sense to you?

Professors

All

Yes

Respond-

General Population, 2000 Election

Study

\begin{tabular}{|c|c|c|c|c|c|c|c|c|c|c|c|}
\hline & \multicolumn{2}{|c|}{ Yes } & \multicolumn{2}{|c|}{ No } & \multicolumn{2}{|c|}{$\begin{array}{l}\text { Respond- } \\
\text { ents }\end{array}$} & & \multicolumn{3}{|c|}{ All } & $B A+$ \\
\hline & $\mathrm{N}$ & $\%$ & $\mathrm{~N}$ & $\%$ & $\mathrm{~N}$ & $\%$ & & $\mathrm{~N}$ & $\%$ & $\mathrm{~N}$ & $\%$ \\
\hline Left & 136 & 6.3 & 30 & 3.1 & 158 & 4.8 & On the left & 357 & 14.4 & 143 & 21.9 \\
\hline 2 & 579 & 26.9 & 100 & 10.1 & 654 & 19.7 & & & & & \\
\hline 3 & 797 & 37.0 & 267 & 27.1 & 1031 & 31.1 & & & & & \\
\hline 4 & 322 & 15.0 & 425 & 43.1 & 720 & 21.7 & On the center & 1060 & 42.7 & 310 & 47.4 \\
\hline 5 & 206 & 9.6 & 115 & 11.7 & 315 & 9.5 & & & & & \\
\hline 6 & 89 & 4.1 & 35 & 3.6 & 115 & 3.5 & & & & & \\
\hline Right & 24 & 1.1 & 13 & 1.4 & 34 & 1.0 & On the right & 492 & 19.8 & 146 & 22.3 \\
\hline NA & & & & & 289 & 8.7 & Not sure & 576 & 23.2 & 55 & 3.4 \\
\hline Total & 2154 & 100.0 & 985 & 00.0 & 3317 & 100.0 & & 2485 & 100.0 & 654 & .0 \\
\hline
\end{tabular}

entists are less polarized on a 10 point scale: $39 \%$ identify themselves as left, $38.4 \%$ as right, and $22.6 \%$ as centre (Berggren et al. 2007).

How do Canadian professors compare to the Canadian general population? A question in the 2000 Canadian Election Study asked a sample of the Canadian population to rate their own political orientation. Respondents were given 4 choices: on the left, on the right, in the centre, and not sure. Following the earlier strategy of collapsing these categories, we notice that professors' left tendency $(25.5 \%)$ is higher than that of the general population (14.4\%) and is somewhat higher than the general population with an undergraduate degree or higher $(21.9 \%)$. The main differences are in university professors being more centrist $(62.3 \%$ versus $42.7 \%$ ) and the general population being more right-leaning (19.8\% versus $4.5 \%$ ). These differences might be related to the average lower levels of education and a higher number of the general population who were unsure of their own political orientation. The more educated tend to be more left-leaning and less unsure than those with less than a university degree.

There is yet another way of addressing the extent of left- and/or rightleaning political orientation of professors and that is to follow Ogmundson to pay attention to voters' own conceptualization of the class position of political parties (Ogmundson 1975a; 1975b; 1976; Pammett 1987; Nakhaie 1992). This is an important consideration not only because voters may view a political party's orientation differently than professional observers, but also because political parties may shift their platforms 
depending on issues or historical events. Therefore, it is important to pay attention to voters' own perception of parties' political orientation.

The survey solicits professors' conceptualizations of the social orientation of the parties as follows, "Some people say that political parties are closer to this social class or that social class. What is your opinion? Where would you locate [name] political party's social orientation?" on a scale of 1 being for the lower class, 4 for the middle class, and 7 for the upper class. Table 4 shows that Canadian professors view all political parties, except for the NDP, to be closer, on average, to the middle-right of the class scale. Among these, Progressive Conservatives scored comparatively far more to the right than other parties (mean=5.55), followed by the Reform (mean=5.07), and Liberal (mean=4.82) parties. The Bloc Québécois scored almost exactly in the middle class (mean=3.95) and NDP more toward the working class (mean=2.80). This clear contrast between NDP versus Liberal and Conservatives is also documented with respect to their electoral candidates and/or elected representatives (see Guppy et al. 1988).

\begin{tabular}{lcc} 
Table 4. Professors' Class Orientation of Political Parties in Canada \\
\multicolumn{1}{c}{ Political Parties } & Mean & \% Missing \\
NDP & 2.80 & 8.8 \\
Bloc Québécois (Quebec only) & 3.95 & 18.9 \\
Liberal & 4.82 & 8.7 \\
Reform & 5.07 & 14.2 \\
Progressive Conservative & 5.55 & 10.6
\end{tabular}

Two contradictory conclusions can be drawn from Tables 2, 3, and 4, depending on the placement of the Liberal Party on a left-right spectrum. If we accept a US-derived political scale that places all parties to the left of the Conservative Party as "left," we can conclude that Canadian universities are dominated by liberal-left leaning professors. If, on the other hand, we accept professors' own assessment of the Liberal Party as a centre-right party, we can conclude that Canadian universities are dominated by centre-right leaning professors, at least in terms of their political behaviour. Only $30 \%$ of professors actually voted for a left party (NDP). More than half voted for parties of the right (Liberal, Conservatives, Reform, and Alliance), at least according to their own definitions.

\section{Multivariate Analysis}

Having showed the party affiliation and political orientation of Canadian professors, we now concentrate on important predictors of party affilia- 
tion. Given the political similarity between, and small number of cases related to, the Reform and PC parties, we combine professors voting for these parties into a conservative affiliation. Moreover, given that Bloc Québécois runs candidates only in federal districts of Quebec, the analyses for this party are limited to the professors teaching in Quebec universities. Finally, since the question for the 2000 vote is an expected and not an actual vote, we focus on the 1997 election. ${ }^{4}$

Tables 5 and 6 show multinomial logits, contrasting the vote for Liberal and/or Conservative parties to that of the NDP. Table 7 presents the logistic regression of voting for the Bloc against the federalist parties. These estimates provide the differences in the log odds of voting for one party compared to another for each predictor. Since the log odds may have little intuitive meaning, the exponentiated coefficients are also presented and discussed. The exponential of a coefficient is the factor by which the odds on vote are multiplied for one unit of change in the predictor variable (e.g., field). For interval and ratio variables, one needs to exponentiate the coefficient and then take it to the power of the desired category.

Tables 5 and 6 present results in blocks. We first introduce the "usual suspects," then we add institutional variables and the final two blocks include generational effects and the liberalism scale. By introducing variables this way, we can see what happens to each as we introduce new sets. For ease of presentation, if a variable is shown to be statistically insignificant in all models, it is deleted from the tables. Insignificant variables include age, rank, and publication productivity. Table 5 shows the odds of voting Liberal as against NDP. It shows that Quebeckers, males, married, visible minorities, Europeans, self-identified Canadians, more religious, and those with higher income are all more likely to vote Liberal than NDP when compared to their reference categories. Among dichotomous variables, the odds of Quebeckers as against Ontarians, and visible minorities as against British, voting Liberal as opposed to NDP is 3.2 and 2.5 times, respectively. Introduction of institutional variables results in weakening the effects of Quebec and marital status and eliminates the significant effects of gender, self-identified Canadian, and income. Among institutional variables, those in the "liberal arts," particularly those in the humanities, social sciences, and education are less likely to vote for the Liberal Party than for the NDP. In contrast, those with higher institutional status, as measured by Gourman ranking, are more often

4. The 1993 and 1997 elections are based on the retrospective accounts of respondents' vote. This could introduce error of recall or bias for or against the dominant party depending on its popularity at the time of survey. Nevertheless, since there is a high voting consistency, we expect that the bias is minimal. 
Table 5. Multinomial Coefficients of Party Affiliation and Predictors: Liberal / NDP

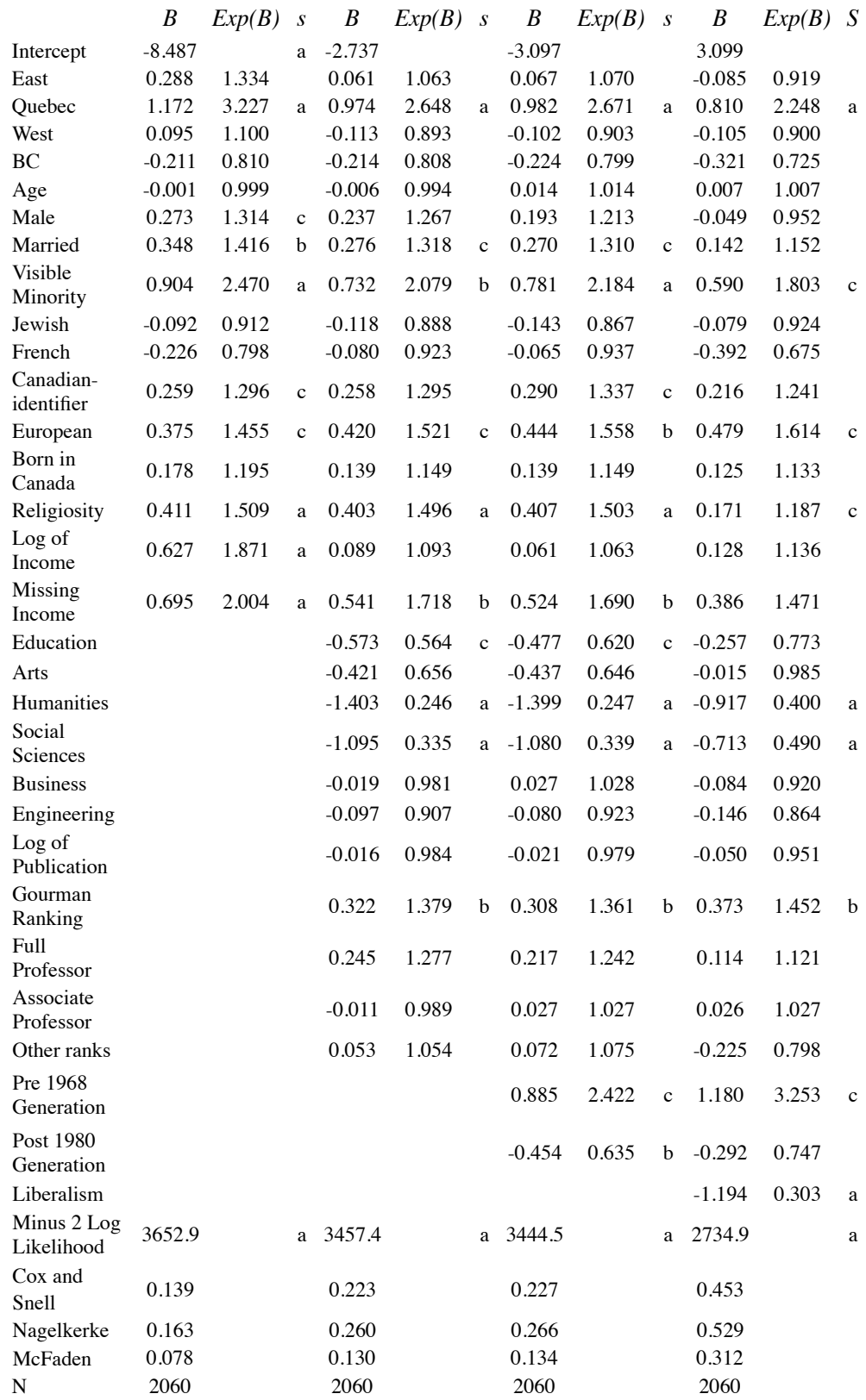

a $\quad \mathrm{p}<.001, \mathrm{~b} \mathrm{p}<.01, \mathrm{c} \mathrm{p}<.05$. 
Liberal than NDP voters (Model 2). The self-identified Canadian effect reappears when generation is included in Model 3, and disappears when liberalism is included in Model 4. Those who acquired their highest degree recently are less often Liberal than NDP voters, when compared to the "radical" generation of the 1960s. The "radical" generation, itself, is less a Liberal voter, and more an NDP voter, than the preceding generation. Finally, Model 4 includes professors' self-rating on the liberalism scale. For ease of discussion, the left-right scale is recoded so that higher scores mean more left (or more liberal) and lower scores means more right (or less liberal).

Table 5 shows that each unit increase in liberalism exponentially decreases vote for the Liberal compare to the New Democratic Party by .303 . Moreover, introduction of liberalism makes the recent generation effect insignificant when compared to the "radical" generation while making stronger that of the preradical generation. Discipline effect also becomes weaker for the humanities and social sciences and insignificant for education. Similarly, the effects of religiosity, visible minority status, and Quebec become weak and that of marital status insignificant. Therefore, liberalism tends to mediate the relationship between generation, discipline, religiosity, marriage, region, and party vote. Professors' vote for the Liberal as against the New Democratic Party is substantially conditioned by their left-right political orientation with those on the right side of the scale voting more for the Liberal party and those on the left side of the scale voting more for the NDP.

Table 6 shows the results for the Conservative/NDP contrast. In this table, Conservatives includes both the Reform and PC parties. This table, in conjunction with Table 5, shows that there are differences in the vote for Conservatives as against Liberals when compared to the NDP. For example, Quebec professors do not differ in their vote for the NDP and Conservative parties as they did for the Liberal Party and the NDP. Furthermore, in the final model, males and married professors are more often Conservative than NDP voters. These predictors are irrelevant for the Liberal/NDP contrast. For the latter, visible minority status, European origin, institutional standing, and generation are important. They are not important for the former. Finally, as might be expected, the effect of liberalism tends to be stronger for the Conservative/NDP than for Liberal/NDP contrasts.

Looking at Tables 5 and 6 differently, the NDP's main source of support tends to be among professors teaching in the humanities and social sciences, in Ontario universities, who are less religious, attended universities during the radical period, and scored higher on the liberalism scale. 
Table 6. Multinomial Coefficients of Party Affiliation and Predictors: Conservative / NDP

\begin{tabular}{|c|c|c|c|c|c|c|c|c|c|c|c|}
\hline & $B$ & $\operatorname{Exp}(B)$ & $s$ & $B$ & $\operatorname{Exp}(B)$ & $s$ & $B$ & $\operatorname{Exp}(B)$ & $s$ & $B$ & $\operatorname{Exp}(B)$ \\
\hline Intercept & -9.707 & & $\mathrm{~b}$ & -2.758 & & & -2.750 & & & 9.263 & \\
\hline East & 0.251 & 1.285 & & -0.063 & 0.939 & & -0.056 & 0.946 & & -0.092 & 0.913 \\
\hline Quebec & -0.041 & 0.960 & & -0.313 & 0.732 & & -0.312 & 0.732 & & -0.352 & 0.703 \\
\hline West & -0.004 & 0.996 & & -0.277 & 0.758 & & -0.277 & 0.758 & & -0.187 & 0.830 \\
\hline $\mathrm{BC}$ & -0.447 & 0.639 & & -0.429 & 0.651 & & -0.431 & 0.650 & & -0.602 & 0.547 \\
\hline Age & -0.010 & 0.990 & & -0.026 & 0.975 & $\mathrm{c}$ & -0.018 & 0.982 & & -0.027 & 0.973 \\
\hline Male & 1.326 & 3.764 & a & 1.290 & 3.633 & a & 1.272 & 3.569 & $\mathrm{a}$ & 0.600 & 1.822 \\
\hline Married & 0.985 & 2.678 & $\mathrm{a}$ & 0.879 & 2.408 & $\mathrm{a}$ & 0.882 & 2.417 & $\mathrm{a}$ & 0.834 & 2.302 \\
\hline $\begin{array}{l}\text { Visible } \\
\text { Minority }\end{array}$ & 0.111 & 1.118 & & -0.212 & 0.809 & & -0.191 & 0.826 & & -0.223 & 0.800 \\
\hline Jewish & -0.851 & 0.427 & $\mathrm{c}$ & -0.965 & 0.381 & $\mathrm{c}$ & -0.984 & 0.374 & $\mathrm{c}$ & -0.785 & 0.456 \\
\hline French & 0.490 & 1.632 & & 0.692 & 1.997 & & 0.713 & 2.040 & $\mathrm{c}$ & 0.423 & 1.527 \\
\hline $\begin{array}{l}\text { Canadian- } \\
\text { identifier }\end{array}$ & 0.367 & 1.443 & & 0.341 & 1.407 & & 0.366 & 1.443 & & 0.443 & 1.557 \\
\hline European & 0.324 & 1.383 & & 0.352 & 1.422 & & 0.363 & 1.437 & & 0.597 & 1.817 \\
\hline $\begin{array}{l}\text { Born in } \\
\text { Canada }\end{array}$ & 0.263 & 1.301 & & 0.214 & 1.239 & & 0.213 & 1.237 & & 0.306 & 1.358 \\
\hline Religiosity & 0.572 & 1.772 & a & 0.571 & 1.770 & $\mathrm{a}$ & 0.573 & 1.773 & $\mathrm{a}$ & 0.294 & 1.342 \\
\hline $\begin{array}{l}\text { Log of } \\
\text { Income }\end{array}$ & 0.496 & 1.642 & & -0.092 & 0.913 & & -0.118 & 0.889 & & -0.120 & 0.887 \\
\hline $\begin{array}{l}\text { Missing } \\
\text { Income }\end{array}$ & 0.778 & 2.176 & $\mathrm{a}$ & 0.509 & 1.664 & & 0.510 & 1.666 & & 0.307 & 1.360 \\
\hline Education & & & & -1.360 & 0.257 & $\mathrm{a}$ & -1.325 & 0.266 & $\mathrm{a}$ & -0.792 & 0.453 \\
\hline Arts & & & & -2.041 & 0.130 & $\mathrm{c}$ & -2.062 & 0.127 & $\mathrm{c}$ & -1.213 & 0.297 \\
\hline Humanities & & & & -2.117 & 0.120 & $\mathrm{a}$ & -2.118 & 0.120 & $\mathrm{a}$ & -1.211 & 0.298 \\
\hline $\begin{array}{l}\text { Social } \\
\text { Sciences }\end{array}$ & & & & -1.983 & 0.138 & $\mathrm{a}$ & -1.980 & 0.138 & $\mathrm{a}$ & -1.222 & 0.295 \\
\hline Business & & & & 0.207 & 1.230 & & 0.237 & 1.267 & & -0.103 & 0.902 \\
\hline Engineering & & & & 0.208 & 1.232 & & 0.211 & 1.235 & & -0.152 & 0.859 \\
\hline $\begin{array}{l}\text { Log of } \\
\text { Publication }\end{array}$ & & & & -0.069 & 0.933 & & -0.072 & 0.931 & & -0.059 & 0.943 \\
\hline $\begin{array}{l}\text { Gourman } \\
\text { Ranking }\end{array}$ & & & & 0.419 & 1.520 & $\mathrm{~b}$ & 0.420 & 1.523 & $\mathrm{~b}$ & 0.320 & 1.377 \\
\hline $\begin{array}{l}\text { Full } \\
\text { Professor }\end{array}$ & & & & 0.071 & 1.074 & & 0.071 & 1.073 & & 0.035 & 1.036 \\
\hline $\begin{array}{l}\text { Associate } \\
\text { Professor }\end{array}$ & & & & 0.040 & 1.041 & & 0.061 & 1.063 & & -0.014 & 0.986 \\
\hline Other ranks & & & & -0.239 & 0.787 & & -0.223 & 0.800 & & -0.365 & 0.695 \\
\hline $\begin{array}{l}\text { Pre } 1968 \\
\text { Generation }\end{array}$ & & & & & & & 0.465 & 1.593 & & 1.000 & 2.718 \\
\hline $\begin{array}{l}\text { Post } 1980 \\
\text { Generation }\end{array}$ & & & & & & & -0.187 & 0.829 & & -0.001 & 0.999 \\
\hline Liberalism & & & & & & & & & & -2.336 & 0.097 \\
\hline
\end{tabular}

a $\mathrm{p}<.001, \mathrm{~b} \mathrm{p}<.01, \mathrm{c} \mathrm{p}<.05$. 
In general, the multinominal models show that all predictors together account for a good portion of variation in voting Liberal and/or Conservative as against NDP. The pseudo $\mathrm{R}^{2}$, as measured by Nagelkerke, Cox and Snell, or McFadden, ranges from 8-16\% for sociodemographics (Model 1), 13-26\% when we add institutional variable or generation effects (Models 2 and 3) and 31-53\% when we include all variables, particularly the liberalism scale. ${ }^{5}$

Finally Table 7 shows the Bloc/federalist contrasts. It shows that university professors' vote for the Bloc as against other parties is primarily a French phenomena. French Quebeckers are 63 times more likely to

Table 7. Multinomial Coefficients of Party Affiliation and Predictors: Bloc / Federalist

\begin{tabular}{|c|c|c|c|c|}
\hline & $B$ & S.E. & $\operatorname{Exp}(B)$ & Sig. \\
\hline Age & -0.020 & 0.026 & 0.981 & \\
\hline Male & -0.108 & 0.350 & 0.898 & \\
\hline Married & -0.915 & 0.287 & 0.401 & a \\
\hline Visible Minority & -0.273 & 1.700 & 0.761 & \\
\hline Jewish & -17.229 & 7438.675 & 0.000 & \\
\hline French & 4.151 & 0.961 & 63.509 & $\mathrm{a}$ \\
\hline Canadian-identifier & -17.572 & 5073.906 & 0.000 & \\
\hline European & 1.688 & 1.087 & 5.407 & \\
\hline Born in Canada & -0.002 & 0.485 & 0.998 & \\
\hline Religiosity & 0.220 & 0.174 & 1.246 & \\
\hline Log of Income & -1.095 & 0.617 & 0.335 & \\
\hline Missing Income & -1.145 & 0.485 & 0.318 & $\mathrm{c}$ \\
\hline Education & 0.526 & 0.683 & 1.692 & \\
\hline Arts & -0.189 & 0.898 & 0.828 & \\
\hline Humanities & -0.412 & 0.421 & 0.663 & \\
\hline Social Sciences & -0.724 & 0.435 & 0.485 & \\
\hline Business & 0.295 & 0.510 & 1.344 & \\
\hline Engineering & -0.443 & 0.563 & 0.642 & \\
\hline Log of Publication & 0.069 & 0.093 & 1.072 & \\
\hline Gourman Ranking & -1.419 & 0.384 & 0.242 & $\mathrm{a}$ \\
\hline Full Professor & 0.190 & 0.477 & 1.210 & \\
\hline Associate Professor & 0.010 & 0.470 & 1.011 & \\
\hline Other ranks & -0.261 & 0.667 & 0.770 & \\
\hline Pre 1968 Generation & 0.971 & 1.191 & 2.640 & \\
\hline Post 1980 Generation & 0.345 & 0.418 & 1.411 & \\
\hline Liberalism & 0.898 & 0.158 & 2.454 & $\mathrm{a}$ \\
\hline Constant & 9.915 & 7.594 & 20221.468 & \\
\hline minus 2 Log Likelihood & 369.4 & & & \\
\hline Cox and Snell & 0.425 & & & \\
\hline Nagelkerke & 0.584 & & & \\
\hline $\mathrm{N}$ & 585 & & & \\
\hline
\end{tabular}

5. $\mathrm{R}^{2}$ is the standard measure of proportion of the variation in dependent variable as explained by independent variable(s). It should be kept in mind that the Pseudo $\mathrm{R}^{2}$ differs from Linear Regression Models in that it uses the deviance rather than variance. 
vote Bloc than their British counterparts in Quebec. Married Quebeckers are less likely to vote for the Bloc than others by about $40 \%$. Gourman's institutional standing decreases, and liberalism increases, the vote for the Bloc Québécois. Bivariate cross examination of Jews and Canadian selfidentifiers shows that none are Bloc Québécois voters. This accounts for the large negative, but insignificant, coefficients for these categories.

\section{Conclusion and Discussion}

The study of class politics has attracted significant attention in Canada and elsewhere. However, little of this research has focused on intellectuals and university professors, particularly in Canada. In this paper, we aimed to fill the void by evaluating the political orientation and affiliation of university professors as the most conspicuous segment of Canadian intellectuals. ${ }^{6}$ Our findings are consistent with other research indicating that Canadian professors are more left-leaning than the general public. However, our generalization is more nuanced in that professors can be viewed as liberal left-leaning when we consider their own orientation and when a vote for the Liberal Party is considered as a left vote. On the latter issue, if we pay attention to professors' own conceptualization of the class position of political parties, their vote seems to suggest that they act on a centrist and/or rightist impulse.

We have also shown that support for political parties tends to operate through the political orientation of professors. That is, the more leftleaning the professors are, the more likely they are to vote for the NDP - and the more right-leaning, for the Liberal, Conservative, and Reform parties. In contrast, "radical generation" (see Klein and Stern 2005) and academic rank are unimportant in professors' voting behaviour. Although income tends to increase vote for the Liberal Party when compared to the NDP, its effect disappears when institutional variables are included in the model. Institutional variables are important predictors of party vote, though the directional effect of the university status is contrary to that observed by Lipset (1975). A higher university status results in higher vote for the Liberal, Reform, and Conservative parties compared to vote for the NDP.

These findings provide an answer to the persistent question emerging from the study of intellectuals: whether their attitudes and behaviours are class-based or not (see Brym 1980; Gagnon 1987; Nakhaie and Brym 1999). This question is part of a larger tradition of the critique of the

6. The focus of this paper is on professors as a segment of institutionalized intellectuals. However, intellectuals are far more diverse and includes writers, journalists, media pundits, artists, etc., some of which may have more impact on society than professors. 
intelligentsia as a whole. Much of this critique has turned on the question of the degree to which cultural workers can or should be "independent" of the social forces around them. Many of the classical German thinkers sought a social sector apart from, or "above," the fray of social conflicts. Max Weber (1946) in his essays on "science as a vocation" and "politics as a vocation" counselled scientists against engagements that could compromise the integrity of their work. Karl Mannheim (1955), while recognizing the legions of writers caught up in the currents of "ideology" and "utopia" of Weimar Germany, nevertheless believed in the possibility of a "free-floating" intelligentsia capable of dispassionate analysis. Mannheim (1955:154) was among those who saw intellectuals as "relatively classless" drawn from "the most diverse social classes and groups with all possible points of views" who are capable of understanding social reality untainted by their class affiliations.

Against this position have been Marxian writers who have denied the possibility of a genuinely Olympian social location from which societies could be observed with disinterest and "objectivity." The Marxian tradition has typically sorted cultural workers into two camps: hegemonic and counter-hegemonic. Antonio Gramsci (1971) discerned "traditional" intellectuals who propagated system-legitimizing ideas at the behest of business, government, and church, opposing them to "organic" intellectuals who advanced the resistant world views of workers and peasants. Some neo-Marxists, including Alvin Gouldner (1979:19) and Erik Olin Wright (1979) have defined intellectuals not merely as one element of a larger class formation but as potentially a class unto themselves because they stand in a common relationship to the means of production. They are the "New Middle Class," often labelled as the "professional-managerial class," or "expert class" whose contradictory location within the class structure makes them "junior partners" in the "system of exploitation." Our findings are critical of both camps. University professors are politically active, somewhat centrist, and at times left-leaning based on their vote and self-identification. More importantly, their political behaviour is based on their social context and ideological orientation. Those in liberal arts and with a leftist ideological self-placement are more likely to vote for a left party. Their voting behaviour is consistent with their own subjectivity while the effect of objective inequality (income) is relatively weak. This is perhaps understandable since class variation in the academy is minimal both in terms of professors' overwhelmingly middle and upper class background and their limited income variation when compared to the general public.

Therefore, if, as Gramsci has stated, it is the struggle to assimilate and to ideologically conquer the intellectuals that is important for class 
dominance or resistance, then resistance is an important aspect of the academy, but primarily in the liberal arts disciplines. We showed that the natural sciences and business disciplines are more right-leaning, while social sciences, humanities, arts, and education are more left-leaning in terms of party affiliation and political orientation. It is perhaps not surprising that the role of social critic is more likely found in the social sciences, humanities, education, and arts and less so in business, engineering, and natural sciences.

Second, disciplines are units of association in which professors spend a large portion of their life. In these associations, common ideas, interests, norms, values, and styles develop, whether as undergraduate and graduate students, or as professors. Their subject defines the problems that they pursue and their association amplifies such ideas and interests. Beyond university boundaries, professors interact with different groups. Applied and natural science disciplines are typically more often in contact with business enterprises than other disciplines, while the social sciences may be more likely to be in contact with disenfranchised populations, or at least civil society actors. These contacts and problems help develop a specific subculture that is more or less critical of the status quo, and more or less supportive of the dominant institutions (Ladd and Lipset 1975).

Third, according to Martin and Szelenyi (1987), professors in natural sciences are more often human capital owners, while those in social sciences, humanities, and arts are cultural capital owners. Martin and Szelenyi theorize that cultural capital owners, all other conditions being equal, are critical of the status quo, while human capital owners may function as junior partners in the system of exploitation. Finally, professors in the "liberal arts" may experience status deprivation as their salary, value of research grants, prestige, and social standing are more often lower than those in natural sciences. Note that professors in high status universities vote more liberal and conservative than NDP.

In sum, any discussion of a growing and influential left in Canadian universities, parallel to the public discourse about American universities, finds little grounding in this data. Such a position would not accurately portray differentiation within universities and ignore significant contextual differences between Canadian and American political systems and the different political affiliation of professors in the two countries. The best overall description of Canadian professors is that they are leftcentrist in political orientation, liberal in voting behaviour, and rightcentrist in terms of professors' own conceptualization of their vote. In all of these, discipline variation is paramount. The Canadian academy 
cannot be treated as a single entity and distinctions must be made among the fields of specialization.

\section{REFERENCES}

Adorno, T., H. Albert, R. Dahrendorf, J. Habermas, H. Pilot, K. Popper. 1976. The Positivist Dispute in German Sociology. New York: Heinemann.

Alford, R.R. 1963. Party and Society. Chicago: Rand McNally.

Balch, S. 2007. Imaginary moderates: An academic report boomerangs. National Association of Scholars Website http://www.nas.org/polArticles. cfm?Doc Id=34 Retrieved: May 20, 2008.

Berggren, N., H. Jordahl, and C. Stern. 2007. The political opinion of Swedish social scientists. The Ratio Institute Website http://www.ratio.se/pdf/wp/ nb hj ls opinions.pdf Retrieved: May 20, 2008.

Boggs, C. 1993. Intellectuals and Crisis of Modernity. New York: State University of New York Press.

Brooks, S. and Gagnon, A. 1987. Social scientists and politics in Canada. Pp. 19-42 in A. Gagnon, ed., Intellectuals in Liberal Democracies. New York: Praeger.

Brym, R. 1980. Intellectuals and Politics. London: George Allen \& Unwin.

Brym, R. and J. Myles. 1989. Social science intellectuals and public issues in English Canada. University of Toronto Quarterly 58(4):442-51.

Cardiff, C.F. and D.B. Klein. 2005. Faculty partisan affiliation in all disciplines: A voter-registration study. Critical Review 17(3-4): 237-255.

Chomsky, N. 1978. Intellectuals and the State. Den Haag, NL: Het Wereldvenster

Gagnon, A.G. 1987. The role of intellectuals in liberal democracies: Political influence and social involvement. Pp. 3-18 in A.G. Gagnon, ed., Intellectuals in Liberal Democracies. New York: Praeger.

Gouldner, A. 1979. The Future of Intellectuals and the Rise of the New Class. New York: Macmillan.

Gourman, Jack. 1998. Gourman Report: Undergraduate Programs (10th Edition). New York: Princeton Review Publishing.

Gramsci, A. 1971. Selections from the Prison Notebooks, Q. Hoare and G. Smith, eds. London: Lawrence and Wishart.

Grant, G. 1965. Lament for a Nation: The Defeat of Canadian Nationalism. Ottawa: Carleton University Press.

Gross, N. and S. Simmons. 2007. The social and political views of American professors. Working Paper, September 24, 2007. 
Guppy, N., S. Freeman and S. Buchan. 1988. Economic background and political representation. Pp. 394-404 in J. Curtis, E. Grabb, N. Guppy, and S. Gilbert, eds. Social Inequality in Canada: Patterns, Problems, Policies. Scarborough, Ontario: Prentice-Hall Canada. Inc.

Halsey, A.H. and M.A. Trow. 1971. The British Academics. London: Faber and Faber.

Hofstadter, R. 1963. Anti-intellectualism in American Life. New York: Knopf.

Horowitz, D. and E. Lehrer. 2002. Political bias in the administrations and faculties of 32 elite colleges and universities. Los Angeles: Center for the Study of Popular Culture.

Jacoby, R. 1987. The Last Intellectuals: American Culture in the Age of Academe. New York: Basic Books.

Jaschik, S. 2007. The liberal and (moderating) professoriate. Inside Higher Education. From website: www.insidehighered.com/news/2007/10/08/politics Retrieved May 2008.

Kimball, R. 199. Tenured Radicals: How Politics has Corrupted our Higher Education. New York: Harper \& Row.

Klein, D. and C. Stern. 2005. Professors and their politics: The policy views of social scientists. Critical Review 17:257-303. 2007. By the number: The ideological profile of professors. http://www. aei.org.event1595. Retrieved May 20, 2008.

Kobayashi, A. 2002. Now you see them, how you see them: Women of colour in Canadian Academia. Pp. 44-54 in S. Heald, ed. Ivory Towers, Feminist Issues: Selected Papers from the WIN Symposia, 2000-2001. Ottawa: Humanities and Social Sciences Federation of Canada.

Ladd, E.C. and S.M. Lipset. 1971. The politics of American political scientists. PS: Political Science and Politics 4(2):135-144. 1973a. Professors, Unions, and American Higher Education. Washington, DC: American Enterprise Institute for Public Policy Research. 1973b. Academics, Politics, and the 1972 Elections. Washington, DC: American Enterprise Institute for Public Policy Research. 1975. The Divided Academy. New York: McGraw-Hill.

Lennards, J. 1990. The Academic Profession in Canada. Toronto: Department of Sociology, Glendon College, York University.

Lipset, S.M. 1996 American Exceptionalism: A Double-Edged Sword. New York: W.W. Norton \& Company.

1970. The politics of academia. Pp. 85-118 in David C. Nichols, ed., Perspectives on Campus Tensions. Washington, DC: American Council on Education. 1972. Rebellion in the University. Boston: Little, Brown.

Lipset, S.M. and R. Dobson. 1972. The intellectual as critic and rebel: With special reference to the United States and the Soviet Union. Daedalus 101:137-198. 
Mannheim, K. 1955. Ideology and Utopia. L. Wirth and E. Shils, trans. New York: Harvest.

Martin, B. and I. Szelenyi. 1987. Beyond cultural capital: Toward a theory of symbolic domination. Pp. 16-49, in R. Eyerman, G. Svensson, and T. Soderqvist, eds., Intellectuals, Universities and the State in Western Modern Societies. Berkeley: University of California Press.

Nakhaie, M.R. 1992. Class and voting consistency in Canada: Analyses bearing on the mobilization thesis. Canadian Journal of Sociology 17(3):275299.

2002. Gender differences in publication among university professors in Canada. Canadian Review of Sociology and Anthropology 39(2):151180.

2007. Universalism, ascription and academic rank: Canadian professors, 1987-2000. Canadian Review of Sociology and Anthropology 44(3):361-386.

Nakhaie, M.R. and B. Brym. 1999. Political attitudes of Canadian professors. Canadian Journal of Sociology 24(3):329-353.

Neuman, L. 2006. Social Research Methods: Qualitative and Quantitative Approaches. New York: Pearson.

Nozick, R. 1998. Why do intellectuals oppose capitalism?. CATO Online Policy Report. Vol. XX. No. 1. Jan/Feb. From website: www.cato.org/pubs/ policy report/cpr-20n1-1.html - 34k - 1998-01-01 Retrieved Dec. 4, 2007.

Ogmundson, R. 1975a. On the measurement of party class positions: The case of Canadian federal political parties. Canadian Review of Sociology and Anthropology 12(November):565-76.

1975b. On the use of party image variables to measure the political distinctiveness of a class vote: The Canadian case. Canadian Journal of Sociology 1(2):169-77.

1976. Mass-elite linkage and class issues in Canada. Canadian Review of Sociology and Anthropology 13(1):1-12.

Ogmundson, R. and J. McLaughlin. 1994. Changes in an intellectual elite 19601990: The Royal Society revisited. Canadian Review of Sociology and Anthropology 31(1):1-13.

Pammett, J. 1987. Class voting and class consciousness in Canada. Canadian Review of Sociology and Anthropology 24(2):270-90.

Pinard, M. and R. Hamilton. 1989. Intellectuals and leadership of social movements: Some comparative perspectives. Research in Social Movements, Conflicts and Change 11:73-107.

Porter, J. 1965. The Vertical Mosaic: An Analysis of Power and Social Class in Canada. Toronto: University of Toronto Press.

Rothman, S., S.R. Lichter, and N. Nevitte. 2005. Politics and professional advancement among college faculty. Article 2 in The Forum, vol. 3 . 
Rothman, S. and S.R. Lichter. 2007. The vanishing conservatives - Is there a glass ceiling? http://www.aei.org.event1595 Retrieved May 20, 2008.

Scatamburlo, Valerie. 1998. Soldiers of Misfortune: The New Right's Culture War and the Politics of Political Correctness. New York: Peter Lang.

Smith, D. 2001. What are intellectuals for. Inaugural Lecture delivered at Loughborough University on May 16th, 2001. From website: http://www.lboro. ac.uk/departments/ss/What Are.htm Retrieved Dec. 4, 2007

Thomson, J.J. 1990. Ideology and faculty Selection. Law and Contemporary Problems 53(3):155-176.

Tremblay, M. 1998. Do female MPs substantively represent women? A study of legislative behaviour in Canada's 35th Parliament. Canadian Journal of Political Science/Revue canadienne de science politique 31(3):435-465.

Weber, M. 1946. Politics as a vocation, Science as a vocation, and "Types of "class struggle." Pp. 184-186 in H. Gerth and C.W. Mills, eds., From Max Weber: Essays in Sociology. New York: Oxford University Press.

Wright, E. 1979. Intellectuals and the class structure of capitalist society. Pp. 191-211 in Pat Walker, ed., Between Labor and Capital. Montreal: Black Rose Books.

Zipp, J.F. 1978. Left-right dimensions of Canadian federal party identification: A discriminant analysis. Canadian Journal of Political Science 11:25177.

Zipp, J.F. and J. Smith. 1982. A structural analysis of class voting. Social Forces 60(3):738-759.

Reza Nakhaie is Professor of Sociology at the Department of Sociology, University of Windsor. His main focus of investigation is in the area of social inequality, the role of equity (justice and fairness) and diversity (various demographic concerns) in Canadian society, in general, and more recently, in higher education. His recent publications appear in Canadian Review of Sociology, Canadian Journal of Sociology, Canadian Political Sciences, Canadian Ethnic Studies, Review of Radical Political Economy, International Migration and Integration, and Journal of School Violence. Website: http://www.uwindsor.ca/nakhaie

Barry D. Adam is University Professor of Sociology at the University of Windsor and Senior Scientist and Director of Prevention Research at the Ontario HIV Treatment Network. He has a lengthy research and publication record on the dynamics of domination and empowerment, LGBT studies, and HIV prevention and issues of living with HIV. He has published four books: The Survival of Domination, Experiencing HIV, The Rise of a Gay and Lesbian Movement, and The Global Emergence of Gay and Lesbian Politics. Website: http://www. uwindsor.ca/adam 
898 C) Canadian Journal of Sociology/Cahiers canadiens de Sociologie 33(4) 2008 